\begin{tabular}{|l|c|c|c|r|}
\hline $\begin{array}{l}\text { Cuadernos de Investigación Geográfica } \\
\text { Geographical Research Letters }\end{array}$ & 2017 & N $^{\circ} 43(1)$ & pp. 41-62 & $\begin{array}{r}\text { ISSN 0211-6820 } \\
\text { eISSN 1697-9540 }\end{array}$ \\
\hline
\end{tabular}

\title{
A MULTISCALE APPROACH TO ASSESS GEOMORPHOLOGICAL PROCESSES IN A SEMIARID BADLAND AREA (EBRO DEPRESSION, SPAIN)
}

\author{
V. FERRER ${ }^{1}$, P. ERREA ${ }^{2}$, E. ALONSO ${ }^{2}$, \\ A. GÓMEZ-GUTIÉRREZ ${ }^{3}$, E. NADAL-ROMERO ${ }^{1 *}$ \\ ${ }^{1}$ Departamento de Geografía y Ordenación del Territorio, Facultad de Filosofía y Letras, \\ Instituto de Investigación en Ciencias Ambientales de Aragón (IUCA), \\ Universidad de Zaragoza, Zaragoza, Spain. \\ ${ }^{2}$ Instituto Pirenaico de Ecología, Consejo Superior de Investigaciones Científicas (IPE-CSIC), \\ Campus de Aula Dei, Apartado 13034, 50080 Zaragoza, Spain. \\ ${ }^{3}$ Grupo de Investigación GeoAmbiental (GIGA), Área de Geografía Física, Facultad de Filosofía y Letras, \\ Universidad de Extremadura, Cáceres, Spain.
}

\begin{abstract}
In this paper, three methods (Terrestrial Laser Scanner (TLS), terrestrial Structure from Motion photogrammetry (SfM) and aerial SfM photogrammetry with an Unmanned Aerial Vehicle (UAV)) were evaluated and compared to produce high resolution point clouds and Digital Elevation Models (DEMs) in a semiarid, complex badland area (Los Aguarales) with tourism activities. Geomorphological processes and dynamics were studied at different spatial scales. The preliminary results showed the possibilities of a multiscale approach, using various non-invasive techniques, to assess geomorphological processes. The high resolution of the point clouds, obtained with TLS and terrestrial SfM photogrammetry, allowed preliminary identification of numerous spatial details, although no relevant topographical changes were detected during a short, wet spring period (with rainfall of $200 \mathrm{~mm}$ ). UAV images allowed work at larger scales (catchment), mapping piping features, and could be seen as a worthwhile tool for time-effective data acquisition from larger areas. The application of different technologies and a multiscale approach to generate high resolution DEMs is a useful technique when carrying out geomorphological studies in semiarid badland areas. However, long term studies will be necessary to verify the suitability of these techniques in such complex landscapes, and quantify topographical changes and erosion rates. Finally, the information obtained with these tools could be used to promote the study area as an interesting geomorphosite with opportunities for tourism.
\end{abstract}




\section{Análisis multiescala para estudiar procesos geomorfológicos en un área acarcavada de ambientes semiáridos (Depresión del Ebro, España)}

RESUMEN. En este trabajo, se evalúan y comparan tres métodos no-invasivos: (i) escáner láser terrestre (TLS), (ii) fotogrametría terrestre y técnicas Structure from Motion (SfM), y (iii) fotogrametría aérea y técnicas SfM a partir de imágenes capturadas con un dron (UAV), para producir nubes de puntos de alta resolución y crear modelos digitales de elevaciones (DEM) en badlands semiáridos muy complejos y con cierta actividad turística (Los Aguarales). Se analizaron los procesos y dinámicas geomorfológicas a diferentes escalas espaciales. Los resultados preliminares demostraron las posibilidades de un enfoque multiescalar, utilizando diferentes técnicas no invasivas, para evaluar diferentes procesos geomorfológicos. La alta resolución de las nubes de puntos, obtenidas con el TLS y la fotogrametría terrestre (SfM), ha permitido identificar numerosos detalles espaciales. Sin embargo, en el periodo de estudio (una primavera húmeda con un registro de precipitación de $200 \mathrm{~mm}$ ) no se han registrado importantes cambios topográficos. Por otro lado, las imágenes obtenidas con el dron y las técnicas fotogramétricas permitieron cartografiar los pipes en la zona de estudio y confirman la viabilidad de esta herramienta para estudiar superficies de mayor tamaño en un corto periodo de tiempo. El uso de tecnologías no invasivas y un enfoque multiescalar para generar DEMs de alta resolución es una perspectiva adecuada y ventajosa para llevar a cabo estudios geomorfológicos en zonas de cárcavas semiáridas. Sin embargo, son necesarios estudios de mayor duración que nos permitan verificar la idoneidad de estas técnicas en paisajes complejos, y cuantificar los cambios topográficos y las tasas de erosión. Por último, destacar que los resultados obtenidos con estas nuevas herramientas podrían ser utilizados para promocionar el área de estudio como lugar de interés geomorfológico y turístico.

Key words: badlands, piping, Terrestrial Laser Scanner, SfM photogrammetry, UAVs.

Palabras clave: badlands, piping, escáner láser terrestre, fotogrametría SfM, dron.

Received: 10 November 2016 Accepted: 15 January 2016

* Corresponding author: E. Nadal Romero, Departamento de Geografía y Ordenación del Territorio, Facultad de Filosofía y Letras, Instituto de Investigación en Ciencias Ambientales de Aragón (IUCA), Universidad de Zaragoza, Pedro Cerbuna 12, 50009 Zaragoza, Spain.E-mail: estelanr@unizar.es

\section{Introduction}

Badland areas show the highest erosion rates in the world (Bryan and Yair, 1982). The development of badlands is one of the most important geomorphic processes in the Mediterranean region, due to erosive rains, steep topography, low vegetation cover, land use changes and high erodibility of some bedrocks (García Ruiz and López Bermúdez, 
2009; García-Ruiz et al., 2013). Badlands mainly develop in arid and semiarid environments, and the magnitude of geomorphological processes makes them "ideal field laboratories" (Gallart et al., 2013), to apply a multiscale approach to understand these processes.

Tunnel and piping processes have been reported in numerous studies linked to semiarid badland areas (Calvo-Cases et al., 2011; Desir and Marín, 2011, 2013; Faulkner, 2013; García-Ruiz et al., 2013) and have been recognised as important processes in controlling gully development (Valentin et al., 2005). Bocco (1991) concluded that around $60 \%$ of badlands in Europe showed evidence of piping, and Higgins (1990) noticed that piping is a source of "many, if not most" gullies in Mediterranean climates in California. Piping is the mechanical removal of soil particles by concentrated subsurface flows (Jones, 2004), which leads to the formation of underground channels, called pipes. These processes are mainly associated with: (i) lithology (abundant expansive clays and high sodium content), (ii) strong hydraulic gradients (due i.e. to gully incision), and (iii) the presence of a less permeable layer at depth (García-Ruiz, 2013).

On badland areas, quantifying soil erosion at high spatial and temporal resolution can be time consuming, costly and logistically difficult. Moreover, piping as a subsurface process is considered one of the most difficult erosion processes to study (Faulkner, 2013), and despite its importance, quantitative data on the contribution of piping to sediment yield are scarce (i.e. Marzolff and Ries, 2011).

Trends in geomorphological and soil erosion studies have recently been reviewed (Piégay et al., 2015; Viles, 2016; García-Ruiz et al., 2017), which emphasizes the dramatic changes that have occurred in the last few decades as a result of technological advances. Church (2010) and Wohl et al. (2016) highlighted the importance of developments in remote sensing technologies to the progress of geomorphology over the last 50 years. More specifically, Nadal-Romero et al. (2015) reviewed the methodologies for analysing geomorphological processes and erosion rates in badland areas. The results showed that the geomorphology of badlands has been extensively studied for the last 30 years, using numerous methods to understand geomorphological dynamics (erosion and deposition processes) and quantify erosion rates. The authors emphasized that from 2007 there has been a sharp increase in topographic data measurements for geomorphic research (Nadal-Romero et al., 2015), and new developments and non-invasive tools have focused on constructing Digital Elevation Models (DEMs) or Digital Terrain Models (DTMs): Structure from Motion photogrammetry (SfM) (Gómez-Gutiérrez et al., 2014, 2016; Castillo et al., 2015; Smith and Vericat, 2015), Terrestrial Laser Scanner (TLS) (Vericat et al., 2014; Bechet et al., 2015), or aerial SfM using Unnamed Aerial Vehicles (UAVs) (D’Oleire-Oltmanns et al., 2012; Neugirg et al., 2016b). These new technologies have provided a set of tools that are dramatically increasing spatial resolution and allowing new kinds of data analysis.

The aim of this research is to assess three methodological tools (TLS, terrestrial SfM convergent photogrammetry and aerial SfM photogrammetry using an UAV) to evaluate and make preliminary identification of geomorphological processes in a semiarid badland area using a multiscale approach. Surface changes and soil erosion processes were 
determined and methods compared at different spatial scales. Some interesting papers (i.e. Neugirg et al., 2016b) have already carried out studies comparing these technologies in badland areas. However, the most interesting point, and the novelty of our study is that the study area (Los Aguarales) presents a high variety of forms and processes that will allow us to compare the different tools in complex abrupt areas, microcatchments or flat areas at different spatial scales.

\section{Materials and methods}

\subsection{Study area: Los Aguarales badlands}

Los Aguarales badlands are located in the Ebro Depression $\left(42^{\circ}\right.$ 9' $9.07^{\prime \prime} \mathrm{N} ; 0^{\circ}$ 49' 2.72" W), a tectonic morphostructure developed during the Alpine tectonic era between the Pyrenees, the Iberian range and the Catalan Coastal range in NE Spain (Figs. 1 and 2A). Los Aguarales badlands occur in the Holocene sediment accumulated in a wide valley infilled with silt and clay (García-Ruiz, personal communication). The lithology is mainly composed of sandstone layers alternating with mudstones. The mineral composition (determined via X-ray diffraction) is quartz (40\%), together with carbonates, mainly calcite (35\%) and dolomite (2\%), and clays: illite (12\%) and chlorite (6\%) (Ferrer, 2016).

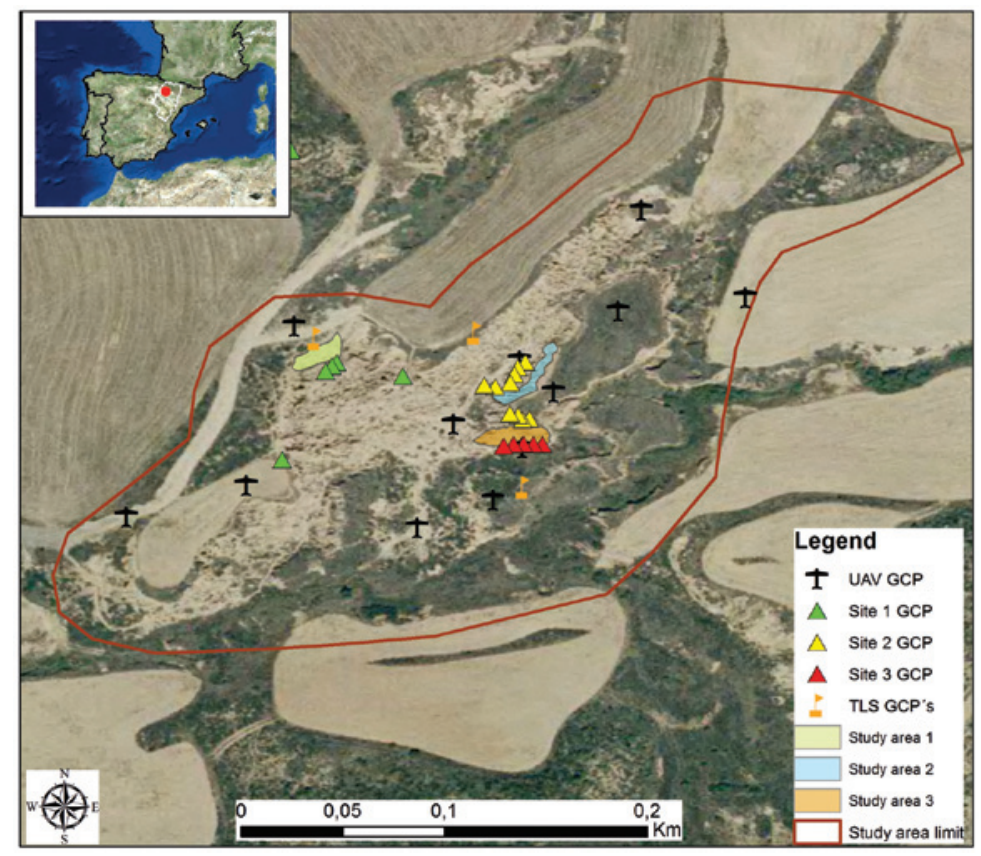

Figure 1. Field site location, Los Aguarales badlands. Detailed image of the selected study sites and location of Ground Control Points, where targets for the indirect registration were placed. 
The increasing hydraulic gradient (due to the incision of the Barreiro Creek) is responsible for the enlargement of the incision to the whole valley and for the high activity of piping processes (Fig. 2). The landscape is abrupt and characterized by a topography consisting of clusters of 1.5-2.5 m-high pinnacles surrounded by vertical slopes and piping collapses of different sizes (Figs. 2C and 2D). The occurrence of gully headcut and small catchments are other interesting geomorphic processes.
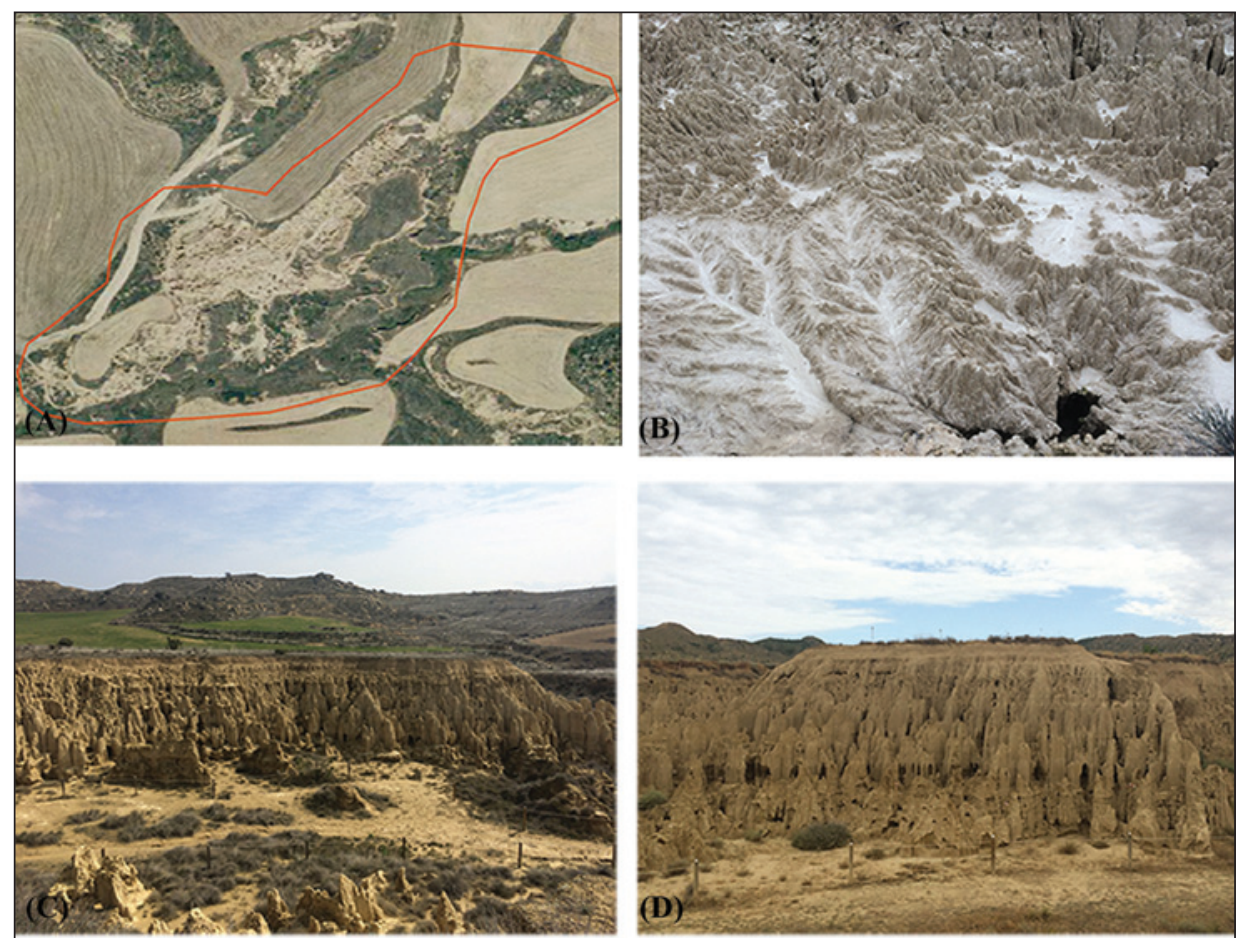

(E)
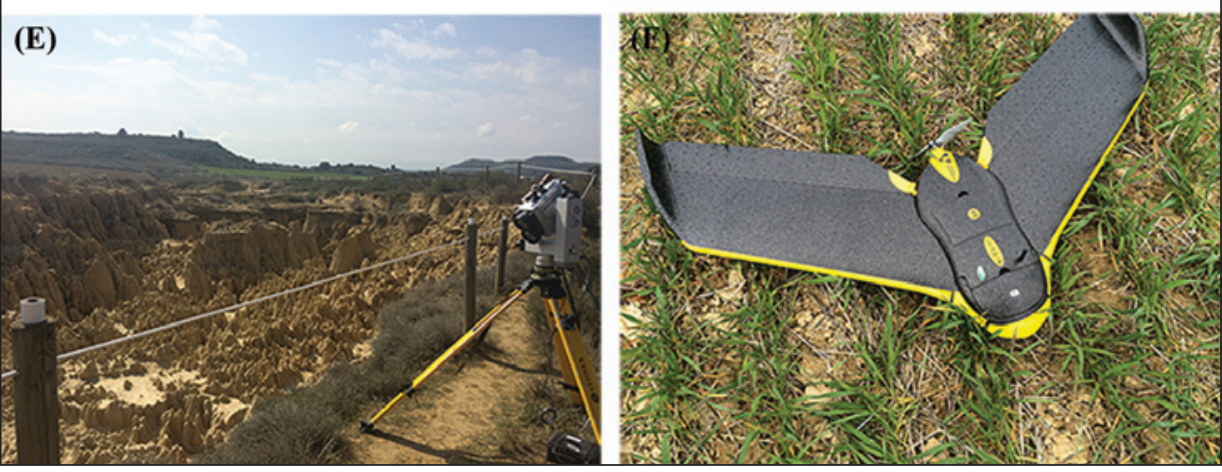

Figure 2. Study sites. (A) Overview from Los Aguarales badlands; (B) Site 1: a small microcatchment with complex fluvial networks; $(C$ and $D)$ Sites 2 and 3: West and South-East oriented vertical slopes (respectively) characterized by the presence of complex pinnacle topography and piping collapses; Site E: Terrestrial Laser Scanner (TLS) surveying Site 1; Site F: fixed wing UAV (Ebbe model, Sensegly company) and Sony WX220 camera. 
Climatically, it is a semiarid area with a mean precipitation of $526 \mathrm{~mm}$, mainly from storms, and distributed in two annual maximums (spring and autumn). The mean annual temperature is $13^{\circ} \mathrm{C}$.

The plant cover distribution and composition have been heavily disturbed by human activities, and agriculture is widespread in the surrounding areas. Natural vegetation is mostly Rosmarinus officinalis and Thymus vulgaris.

We selected three different representative areas to carry out a detailed analysis of the geomorphological processes.

* Site 1 corresponds to a small flat area, where small micro-catchments with perfect and complex fluvial networks occur (approximately $8-10 \mathrm{~m}^{2}$ in size) (Fig. 2B). Piping processes were also observed.

* Sites 2 and 3 (with different orientation). Abrupt, vertical slopes, characterized by a topography of high pinnacles (around $2.5 \mathrm{~m}$ ), and piping collapses (Fig. 2C and 2D).

\subsection{Data acquisition}

Three different methodological approaches based on LiDAR (Light Detection and Ranging) and SfM techniques (terrestrial and aerial images) were tested together for monitoring badland dynamics and geomorphological processes in a semiarid badland area.

Measurements with TLS and terrestrial SfM photogrammetry were performed in March and July 2016 (after a rainy spring period). However, only one field campaign was carried out with the UAV in March 2016.

In order to geo-reference the different data sets (TLS, terrestrial and aerial SfM photogrammetry) into the same absolute coordinate system, we used indirect registration. Indirect target-based registration with a differential GPS (sub-centimetre scale) (LEICA VIVA HS15 CS10 GNSS) was used to merge the information from different methods and samplings. We used between 5 and 10 reflective targets placed at the same positions in the study sites (see Fig. 1). In the case of the UAV, the Ground Control Points (GCPs) need to be spread over the study area; hence 10 different GCPs were registered following the distribution showed in Figure 1.

The post-processing to compare all the point clouds and determine the topographical differences between methods and dates was carried out using the CloudCompare software (Girardeau-Monaut et al., 2005, http://www.danielgm.net/cc/), which generates maps of distances between clouds of points.

\subsubsection{Terrestrial Laser Scanner (TLS)}

A long-range TLS (RIEGL LPM-321) (LiDAR technology) was used in this research (see Revuelto et al., 2014 and Nadal-Romero et al., 2015 for details on technical characteristics, the procedure used for scanning and for the post-processing information). 
Once the formal steps were completed (atmospheric correction, scan of targets and delimitation of the area of interest), the scan of selected sites was carried out. On completion of the scan, photographs were taken using a digital camera coupled to the scanner to capture useful RGB (red-green-blue) information at each point.

The average resolution in point cloud acquisition and the angular scanning are shown in Table 1.

Table 1. Detailed information about point acquisition in the different study sites.

\begin{tabular}{|c|c|c|c|c|c|}
\hline & \multirow{2}{*}{ Surface } & Site 1 & Site 2 & Site 3 & Catchment \\
\hline & & $121.65 \mathrm{~m}^{2}$ & $705.12 \mathrm{~m}^{2}$ & $289.98 \mathrm{~m}^{2}$ & 4.16 ha \\
\hline \multirow{3}{*}{ TLS } & $\begin{array}{l}\text { Resolution in } \\
\text { point cloud } \\
\text { (points } \mathrm{m}^{-2} \text { ) }\end{array}$ & $\sim 3000$ & $\sim 1700$ & $\sim 5000$ & - \\
\hline & $\begin{array}{l}\text { Angular } \\
\text { scanning } \\
\text { resolution }\end{array}$ & $\begin{array}{l}X=0.113 \\
Y=0.113\end{array}$ & $\begin{array}{l}X=0.036 \\
Y=0.036\end{array}$ & $\begin{array}{l}X=0.033 \\
Y=0.033\end{array}$ & - \\
\hline & Targets & 5 & 8 & 8 & - \\
\hline \multirow{4}{*}{$\begin{array}{c}\text { Terrestrial SfM } \\
\text { photogrammetry }\end{array}$} & $\begin{array}{l}\text { Resolution in } \\
\text { point cloud } \\
\text { (points } \mathrm{m}^{-2} \text { ) }\end{array}$ & 1300 & 2300 & 1500 & - \\
\hline & Targets & 5 & 8 & 8 & - \\
\hline & $\begin{array}{l}\text { Number of } \\
\text { photos }\end{array}$ & 18 & 28 & 18 & - \\
\hline & Distance $(\mathrm{m})$ & 9.6 & 7.8 & 8.4 & - \\
\hline \multirow{3}{*}{$\begin{array}{c}\text { Aerial SfM } \\
\text { UAVs }\end{array}$} & $\begin{array}{c}\text { Resolution in } \\
\text { point cloud } \\
\left(\text { points } \mathrm{m}^{-2}\right)\end{array}$ & - & - & - & 2900 \\
\hline & Targets & - & - & - & 11 \\
\hline & $\begin{array}{l}\text { Number of } \\
\text { photos }\end{array}$ & - & - & - & 462 \\
\hline
\end{tabular}

\subsubsection{Terrestrial Structure from Motion photogrammetry}

Structure from Motion (SfM) photogrammetry allows 3-D models to be created from multiple overlapping images taken at distinct triangulation angles. In this study, we used a FUJIFILM Finepix x100 camera with a focal length of $23 \mathrm{~mm}$ (equivalent to a fixed lens of $35 \mathrm{~mm}$ ) and a resolution of $12 \mathrm{Mpx}$ (4288 px x 2848 px) (see NadalRomero et al., 2015 for details). The pictures were taken by hand following a set walking convergent itinerary, and several GCPs where placed to georeference the 3D model. The pictures were processed with Agisoft Photoscan Professional Edition ${ }^{\circledR}$ software, generating a 3-D point cloud of the study sites.The number of pictures (taken by hand) at each site and the spatial resolution of the generated point clouds are shown in Table 1. 


\subsubsection{Aerial Structure from Motion photogrammetry (UAV)}

Aerial images were acquired using a fixed wing UAV (popularly known as a drone) during the first field survey in March 2016. The flight was carried out using the Ebee model (Sensefly Company) carrying on board a Sony WX220 camera with a resolution of 18.2 Mpx. Flight height was about $50 \mathrm{~m}$. The flight track was pre-programmed and designed using Emotion2 software and the different parameters (flight height, overlap, etc.) were set to ensure the highest final resolution and precision in the resulting cartographic products (i.e. point cloud, orthomosaic and DEM). The photographs acquired by the Ebee were georeferenced as the UAV incorporates a GPS receiver (precision 3-5 m), however, GCPs registered by means of a DGPS were necessary in order to obtain precision in the centimetre range (see section 2.2). After the flight, the UAV track and the photographs were downloaded and joined using Emotion2 software (see Table 1). Finally, the dataset was processed using Pix4D software to produce the dense point cloud, the orthomosaic and the DEM.

\section{Results}

Measurements with TLS and terrestrial SfM photogrammetry were performed in March and July 2016. During this period, total rainfall was $186 \mathrm{~mm}$. Three large rainy events were identified during this period with 29.4, 21.6 and $57 \mathrm{~mm}$ on March 19, April 4 and May 9-10, respectively.

The results are structured in three sections. In the first section, the results obtained with the TLS and terrestrial SfM photogrammetry data are presented. The second section presents the comparison between both methodologies. And finally, the information obtained with the UAV is examined and analysed.

\subsection{Terrestrial Laser Scanner (TLS) and Terrestrial SfM photogrammetry}

Observed topographical changes over the study period survey interval in the three selected sites using TLS and terrestrial SfM data are presented in Figures 3 and 4. Negative values (blue colours) reflect erosion, while positive values (red colours) reflect deposition. In general, erosion processes were located in the upper parts of the sites, and small accumulations were recorded in the collapsed areas and at the outlets of the piping systems. Measured topographical changes, with both methods, were very low, and these values fall within the range of the acquisition error of the devices used $(2-6 \mathrm{~cm})$.

Regarding TLS data, small topographical changes were recorded in all the sites (Fig. 3), with very high standard deviation, especially in Sites 2 and 3 (due probably to topographic shadows and longer distance of data acquisition) (Table 2).

SfM data represented the badland surface in more detail, although small topographical changes were also recorded. In the Site 1 (small flat catchment, Fig. 2B), the mean value was around $0.00002 \mathrm{~m}$ (Fig. 4A and Table 2). Signs of rill development were observed. The highest differences were recorded in Site 2, with a mean value around $-0.0005 \mathrm{~m}$ (Fig. 4B and Table 2). In Site 3, the mean difference was 0.00002, registering the highest standard deviation (0.028) (Fig. 4C and Table 2). 
Table 2. Mean differences and standard deviation of point clouds obtained with TLS and terrestrial SfM photogrammetry and the comparison of both methods for both surveys in the three selected sites.

\begin{tabular}{ccccc}
\hline & & Site 1 & Site 2 & Site 3 \\
\hline \multirow{2}{*}{ TLS } & Mean (m) & -0.0009 & -0.0008 & -0.0058 \\
\cline { 2 - 5 } & SD & 0.0148 & 0.0551 & 0.0576 \\
\hline $\begin{array}{c}\text { Terrestrial SfM } \\
\text { photogrammetry }\end{array}$ & Mean (m) & 0.00002 & -0.00049 & 0.00002 \\
\cline { 2 - 5 } $\begin{array}{c}\text { TLS-Terrestrial SfM } \\
\text { (spring) }\end{array}$ & SD & 0.0158 & 0.01846 & 0.02811 \\
\cline { 2 - 5 } & Mean (m) & -0.0012 & -0.0006 & -0.0029 \\
\hline $\begin{array}{c}\text { TLS-Terrestrial SfM } \\
\text { (summer) }\end{array}$ & Mean (m) & -0.0320 & 0.0355 & 0.0525 \\
\cline { 2 - 5 } & SD & 0.0362 & -0.0041 & -0.0027 \\
\hline
\end{tabular}
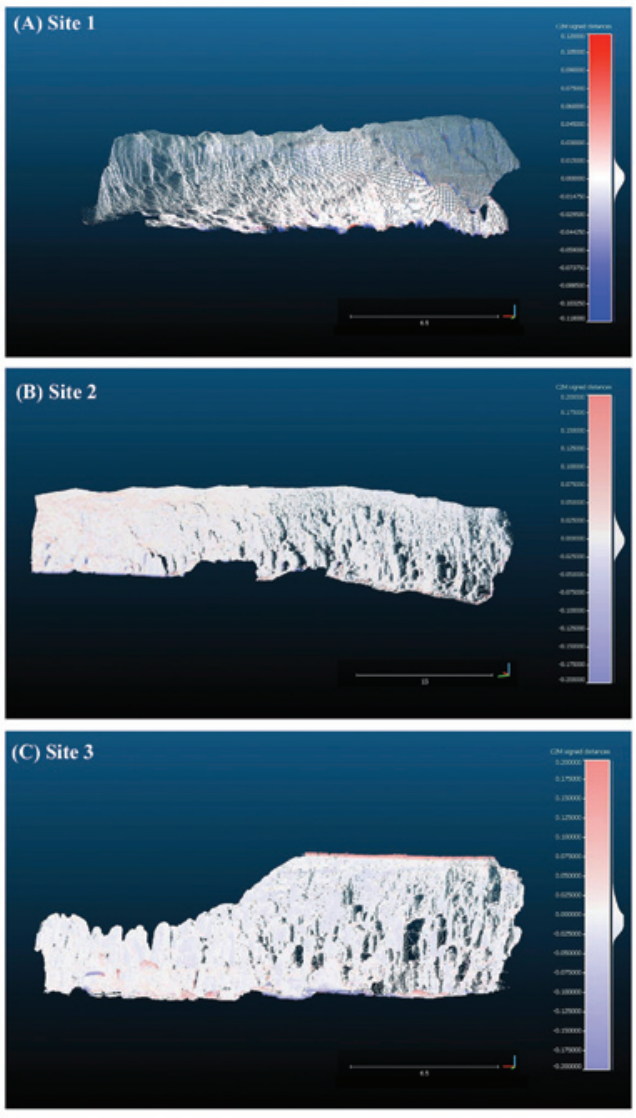

Figure 3. Topographical changes observed at the different sites (Site 1 (A), Site 2 (B) and Site $3(C)$ ) obtained with TLS LiDAR (CloudCompare software). Please note, that different scales are included. 

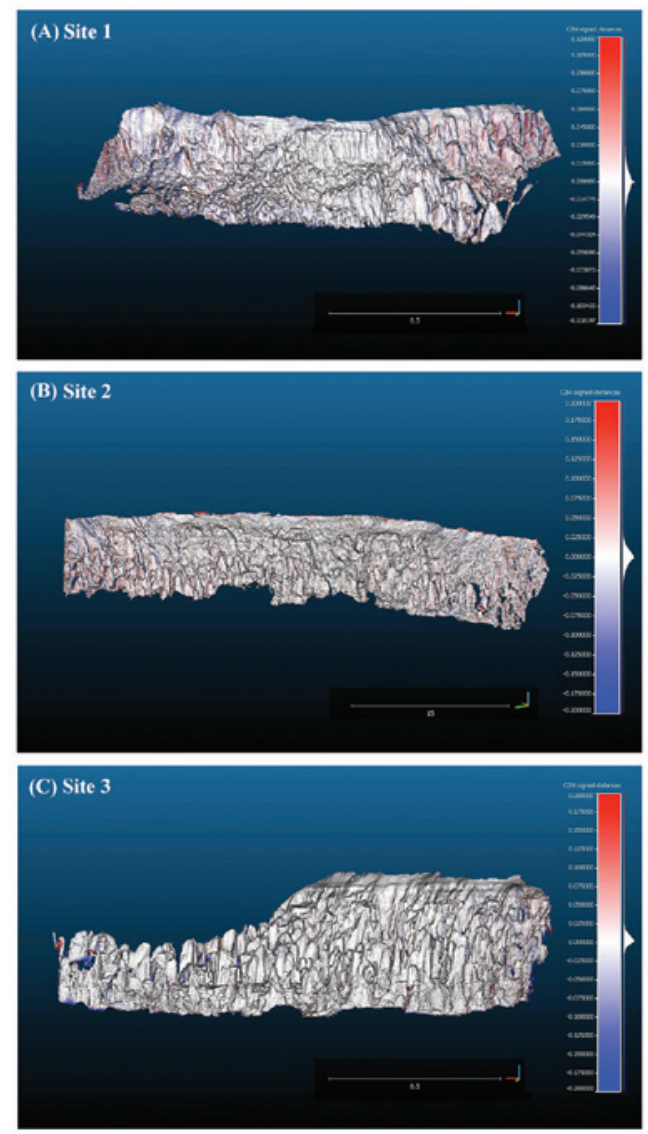

Figure 4. Topographical changes observed at the different sites (Site 1 (A), Site 2 (B) and Site $3(C)$ ) obtained with terrestrial SfM photogrammetry (CloudCompare software). Please note, that different scales are included.

\subsection{Joint analysis}

Differences between TLS and terrestrial SfM photogrammetry were analysed (Fig. 5) by comparing the obtained $3 \mathrm{D}$ point clouds of both techniques, with TLS taken as the reference. In all the cases, the variability of topographical changes was very high, as indicated by the high standard deviation values (Table 2). The smallest differences were recorded in Site 1 (small area and short distance). In Site 2, the highest differences between the two methodologies were recorded in July 2016, due to the increase in distance of data acquisition, and the abrupt and complex morphology (see Fig. 2C). The highest differences were observed in zones where pinnacles and craggy micro-reliefs were observed (see Fig. 5), probably due to the presence of shadows recorded with the TLS ("line of sight effect"). This is one of the limitations of working with TLS using only one scanner position (there is only one point of view and consequently some areas 
are hidden and shadows occur). However, in this case, and due to the special morphology of pinnacles and micro-reliefs, shadows can also be lost with photogrammetry.
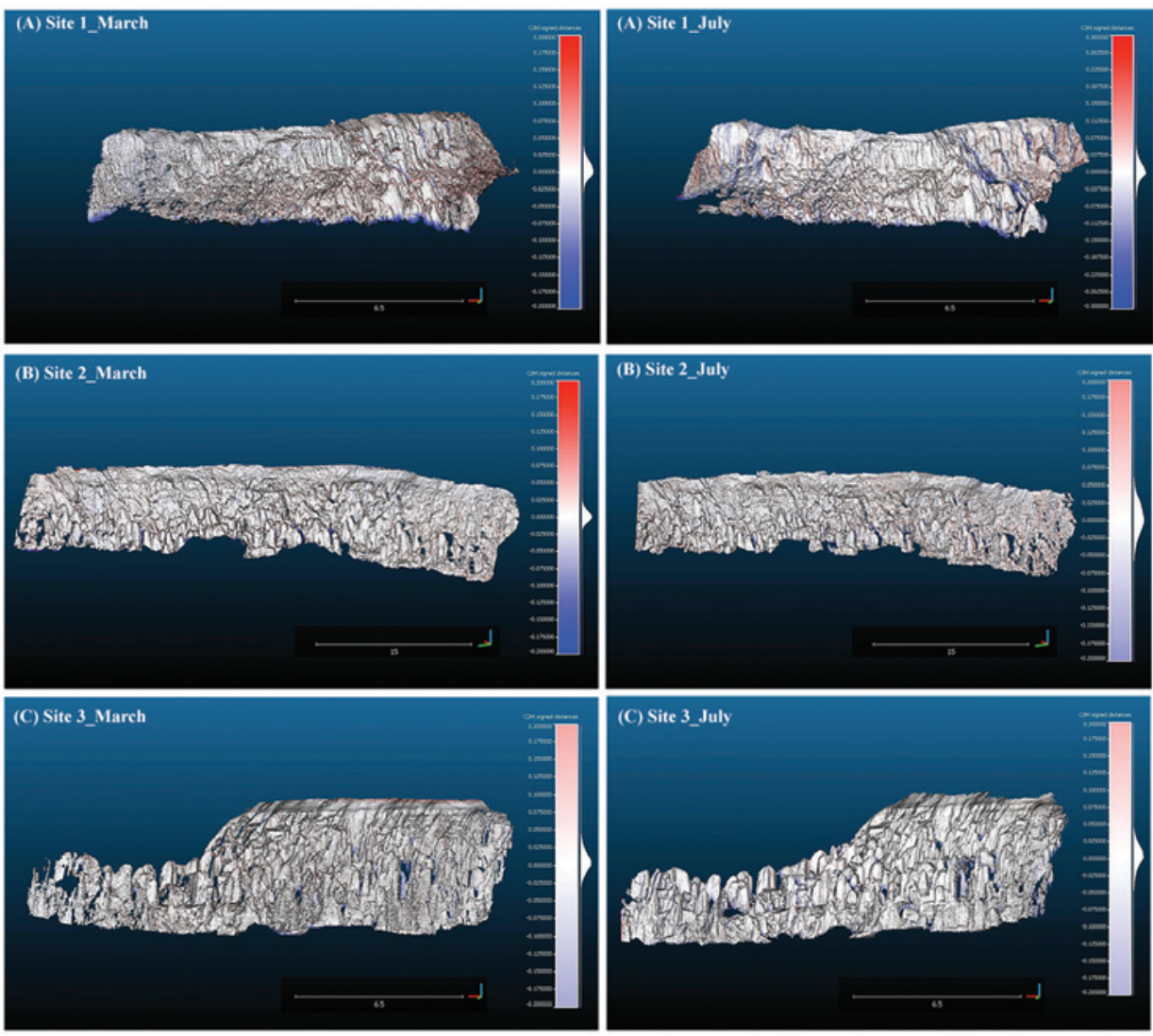

Figure 5. Comparison of point clouds between techniques, taking TLS as the reference at the different sites (Site 1 (A), Site $2(B)$ and Site $3(C)$ ) (CloudCompare software). Please note, that different scales are included.

\subsection{Aerial Structure from Motion photogrammetry (UAV)}

Aerial images were acquired only during the first field survey in March 2016. Consequently, the results are limited and long-term studies and seasonal flights are needed to generate high resolution DEMs to compare topographical changes. Large landforms at catchment scale could be easily identified (see Fig. 6), however smaller forms were not so easily detected.

Comparison between TLS and aerial SfM is not straightforward, as the line of sight effect produces a point cloud with high variability in point density for the TLS. On the other hand, the point cloud resulting from aerial SfM presents a more homogeneous point density 
but with lower absolute point density values. The aerial perspective and the distance to the ground are the factors causing this pattern in aerial SfM point cloud. In order to provide differences between TLS and aerial SfM point clouds, three detailed areas within Sites 1, 2 and 3 were selected. The comparison was carried out in walls with similar point densities and without large shadow surfaces for the TLS. Figure 7 shows the spatial distribution of distances between TLS and aerial SfM for these detailed study sites. Average distances were $0.08 \mathrm{~m},-0.07 \mathrm{~m}$ and $-0.07 \mathrm{~m}$, respectively. These figures should be interpreted carefully because they are highly influenced by both the height of the flight and the location of the TLS from the wall. Additionally, the georefencing Root Mean Square Error of the Aerial SfM point cloud $(\approx 5 \mathrm{~cm})$ performs here as a limiting threshold. Despite this, Figure $7 \mathrm{~B}$ shows a relationship between landform and distance between point clouds, with the larger negative values located in the summit of pinnacles and the larger positive figures happening in concave-depressions of the wall. This pattern is not clearly visible in Figures 7A and 7C.

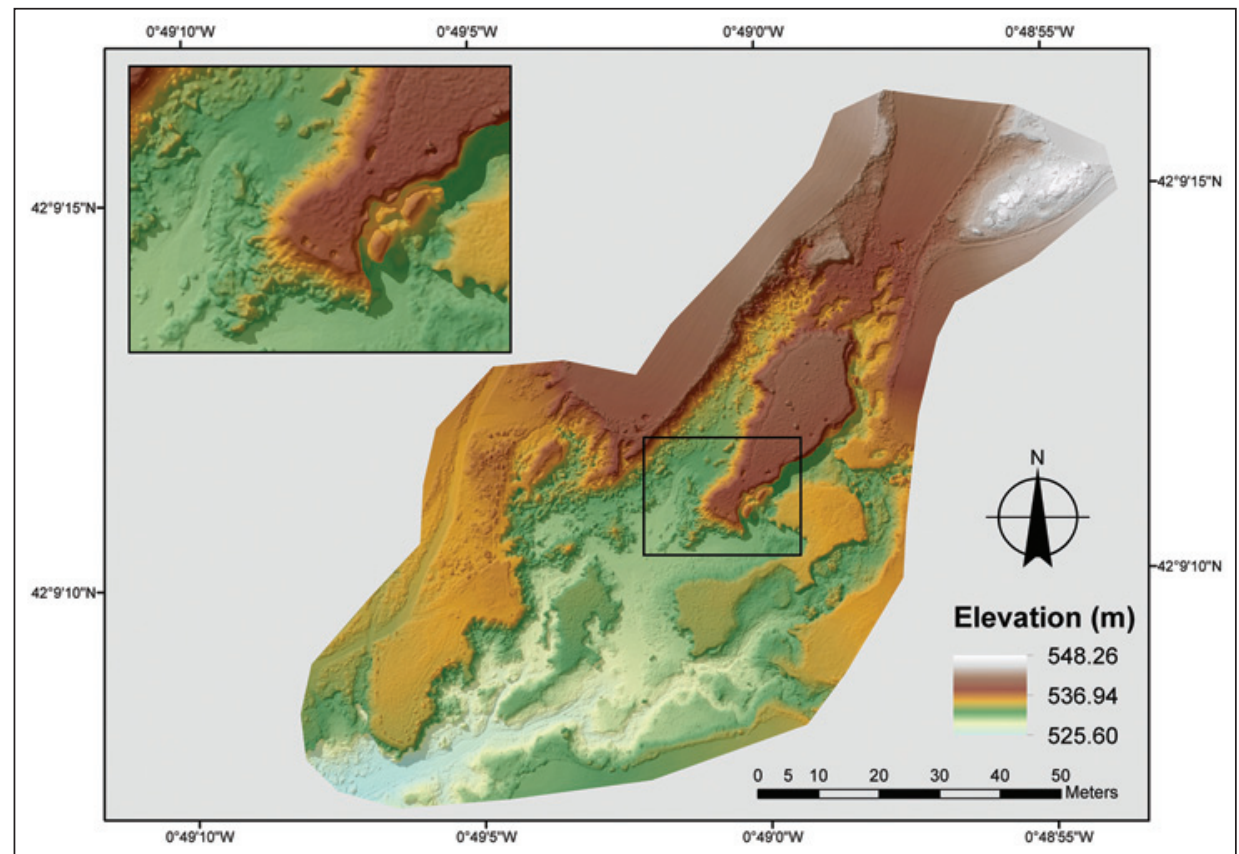

Figure 6.DEM derived from UAVs images captured in spring 2016 at $2 \mathrm{~cm}$ pixel resolution. The enlarged area zoomed in this figure corresponds with the upper part are of the selected Sites 2 and 3.

In Los Aguarales badlands, 115 piping forms were mapped through field work and detailed aerial images obtained by UAV (Fig. 8). The mean diameter of the pipes and collapsed pipes mapped was about $0.84 \mathrm{~m}$ with a maximum diameter of $6 \mathrm{~m}$. The surface area of these pipes also showed a high variability, with a mean value of $1.27 \mathrm{~m}^{2}$ and a standard deviation of $3.5 \mathrm{~m}^{2}$ (minimum $0.01 \mathrm{~m}^{2}$ and maximum $28.6 \mathrm{~m}^{2}$ ). The density of the study area was about 25 pipes/ha. 

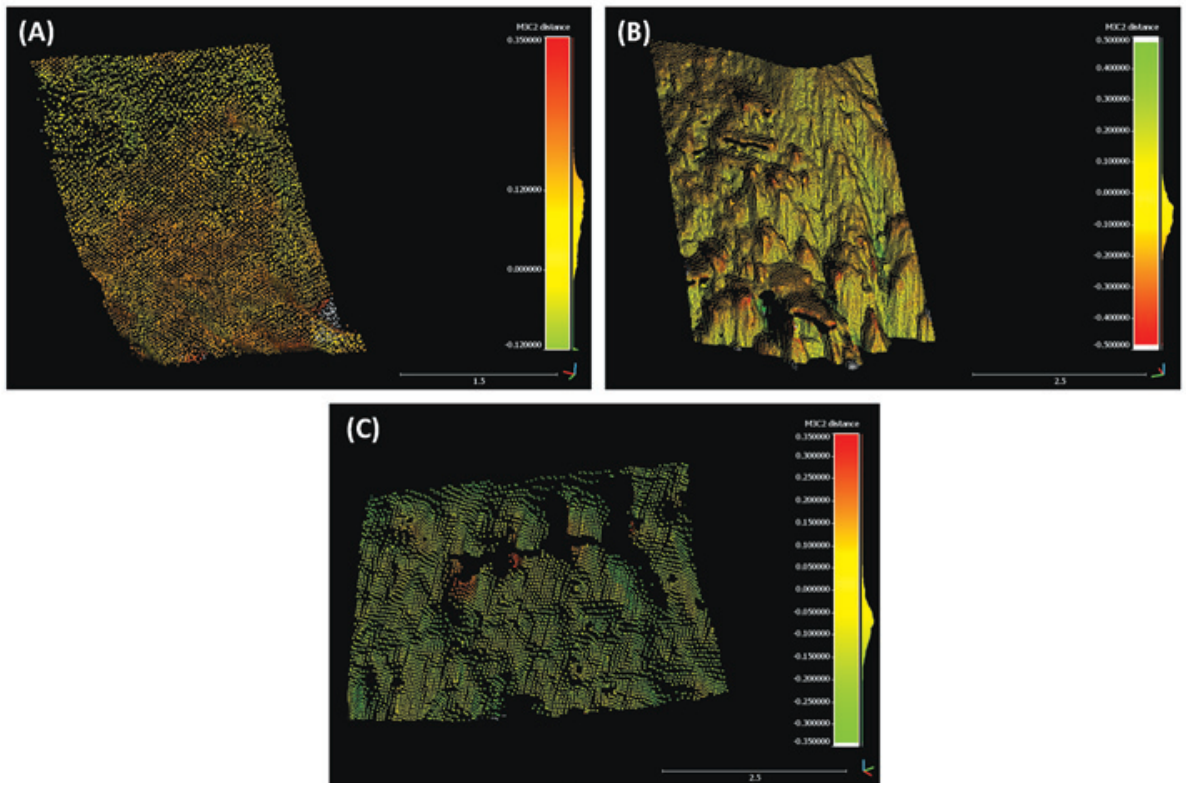

Figure 7. Average distance between the TLS and Aerial SfM point clouds for three detailed surfaces in Sites $1(A), 2(B)$ and $3(C)$. Please note, that different scales are included.

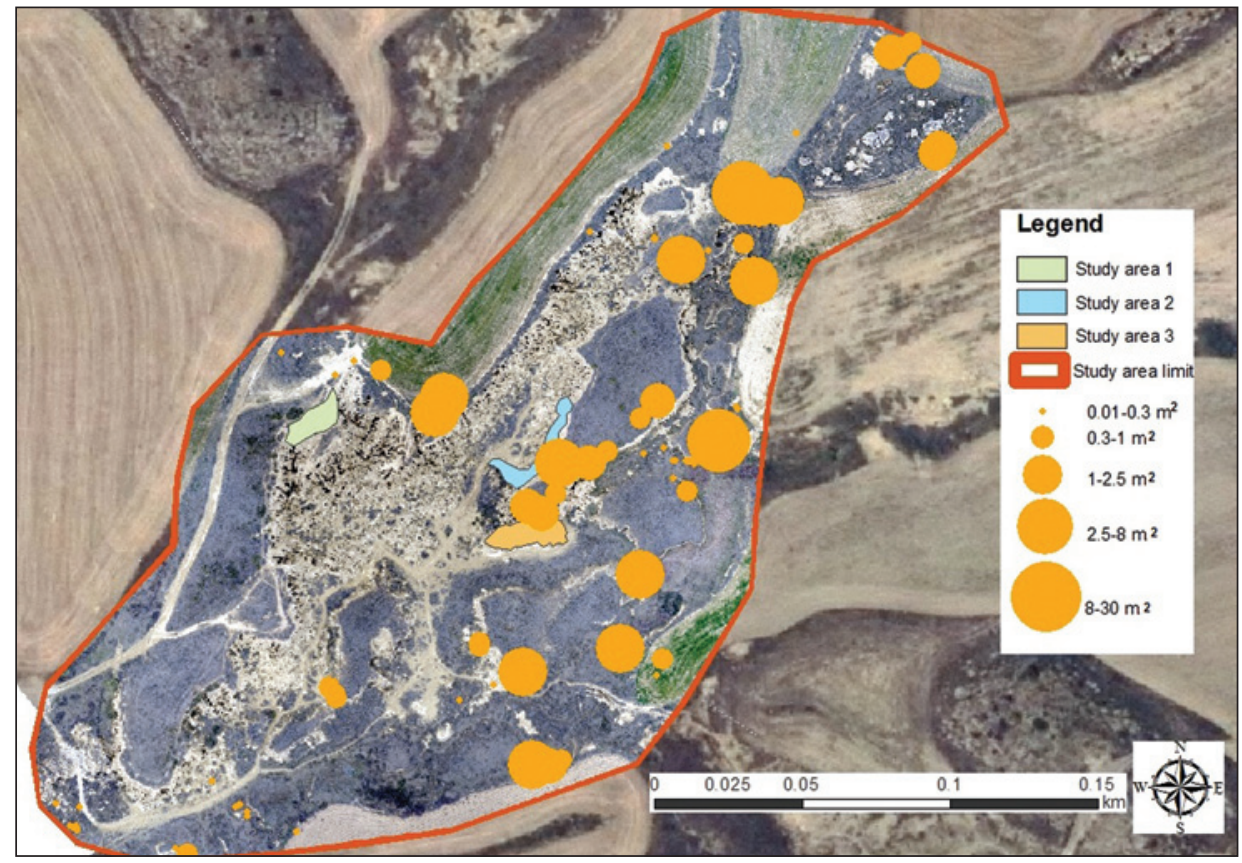

Figure 8. Pipe location and size in Los Aguarales badlands through UAVs images captured in spring 2016 at a $2 \mathrm{~cm}$ pixel resolution. The size of the circles represents the area of the pipes. 


\section{Discussion}

\subsection{Geomorphological dynamics: first approach}

It is noteworthy that geomorphological processes have been defined as scaledependent (Cammeraat, 2004), and certain processes occur at distinct scales that result in a remarkable range of erosion rates (García-Ruiz et al., 2015). García-Ruiz (2015) stated that small and large scales are difficult to integrate, being one of the main problems in geomorphological studies. Consequently, geomorphological processes require information at different spatial scales, and to this end we applied a multiscale approach to assessing geomorphological processes in a semiarid badland area in the Ebro Depression (Spain).

The morphology of Los Aguarales badlands is complex, making the geomorphological interpretation a difficult task. Los Aguarales badlands are characterized by the sequence of incision and piping processes developing an abrupt and complex landscape. Following the "Badland Process Diagnosis Maze" proposed by Faulkner (2013) to determine a field process diagnosis, we can hypothesize that Los Aguarales badlands is an area of predominantly pipe-origin gullies. It was observed in the field and images that as pipe roof collapses occur along the pipe network, they form discontinuous "hammer-heads", producing pinnacles and ruins. Also, Ries and Marzolff (2003) in the Ebro Depression, showed fast evolution of badland areas due to pipe dynamics and collapses, resulting in a chaotic morphology. Piping as a subsurface erosion process is still considered one of the most difficult ones to study, and it seems that all investigation leads to its surface being underestimated (Martínez-Casasnovas, 2003; García-Ruiz, 2011). Bernatek-Jakiel and Kondracka (2016) suggested that mapping pipes and collapsed pipes is the most common method of pipe detection. The images captured with the drone reveals piping distribution (Fig. 8). In Los Aguarales badlands, 115 piping forms were mapped through field work and detailed aerial images obtained by UAV, showing a very high pipe density. It is also important to highlight the pipes outside the badland area, just on the borders, with some located in cultivated areas. These pipes could cause a high hydraulic gradient, generating new collapses and the expansion of these badland areas.

Faulkner (2013) recommended geochemical material analyses of deep subsoil to test the Badland Process Diagnosis. To that end, Ferrer (2016) made a preliminary characterization of the crust and $0-5 \mathrm{~cm}$ material from different forms, showing sodium absorption ratios (SAR) between 3 and 12, suggesting moderately dispersive soils (Faulkner et al., 2004). These dispersive values, together with moderate percentages of dispersive clay content (12\% of illite), low bulk density materials (about $1.2 \mathrm{~g} \mathrm{~cm}^{-3}$ ) that improve infiltration properties, and the presence of burrows, macropores, tension and desiccation cracks and large hydraulic gradients could determine pipe development and landscape evolution in Los Aguarales badlands.

However, we need to survey for longer periods of time with different approaches before geomorphological annual dynamics can be defined. New field work carried out in autumn 2016, and long-term studies using aerial SfM photogrammetry would help in understand piping dynamics. 


\subsection{New technologies}

Geomorphological studies in badland areas have been carried out using a wide variety of methods at different spatial and temporal scales (Nadal-Romero et al., 2008; Martínez-Murillo et al., 2013; Mathys et al., 2003; Vergari et al., 2013; Ballesteros et al., 2015; Nadal-Romero et al., 2015). However, there was a lack of adequate methods for monitoring geomorphological processes, with high spatial resolution, and without soil disturbance (really important in such degraded and sometimes protected environments).

The methods used in this research, which generate dense high resolution point clouds and DEMs, have been shown to be interesting tools to measure soil erosion and identify geomorphological processes and surface changes in badland areas. They have been extensively used in the last five years for erosion studies in the Mediterranean region (D’Oleire-Oltmanns et al., 2012; Kaiser et al., 2014; Vericat et al., 2014; Eltner et al., 2015; Neugirg et al., 2016a, 2016b) providing a good opportunity to safely measure landscapes without soil disturbance, with high spatial resolution and in a relatively short time. Several papers have already investigated the accuracy and comparability of different methods to create DEMs, and have provided detailed assessment of the performance and techniques for different purposes (i.e. Eltner and Baumgart, 2015; Nadal-Romero et al., 2015), but fewer studies have carried out a multiscale approach (i.e. Smith and Vericat, 2015).

A high variety of methods exist to collect data with sufficient coverage and resolution to quantify soil erosion rates and the full spectrum of erosion processes in semi-arid badland areas (Fig. 9), from detailed ones, such as splash erosion, to erosion and connectivity at catchment scale. TLS has been proved to be an effective tool in badland areas (Vericat $e t$ al., 2014; Nadal-Romero et al., 2015). However, in Los Aguarales badlands, the methods used have not revealed any significant topographical changes. These results could be due to the short time of the SfM and TLS surveys, and also to the complex morphology of the study area. The TLS showed lower resolution, and in general the spatial extent was smaller. This limitation can be solved if different scan positions are taken into account, although this would increase the time needed for scanning. It should be noted that new expensive TLS could provide faster image acquisition and higher resolution. As a strength of this technique it should be highlighted the accuracy on the distance acquisition over long range (the device we used reaches $6 \mathrm{~km}$ with a $25 \mathrm{~mm}$ accuracy, distances that UAV and terrestrial SfM cannot reproduce with similar accuracies).

Smith and Veriat (2015) found that SfM photogrammetry reveals a scale-dependent practicability, and they indicated that it is more useful in small-scale studies (hillslopes, plots), whereas error behaviour is not an advantage for larger scales (i.e. catchments). Moreover, Eltner et al. (2016b) showed that SfM can be applied across a large range of scales measuring from a few $\mathrm{cm}$ up to few $\mathrm{km}$ (median scale amounts to about $100 \mathrm{~m}$ ), and they concluded that SfM is restricted to areas $<1$ ha. Our study has demonstrated the applicability of this technique, although longer study periods will be necessary.

Aerial photography taken by UAVs could be an excellent tool in understanding badland dynamics at larger scales (Kaiser et al., 2014; Neugirg et al., 2016b). It is an ideal tool to map piping forms (see Fig. 8) or connectivity at catchment scale, but in its 
present form we deem it unsuitable for identifying other detailed soil erosion processes. One of the reasons for these limitations is the flying height and platform characteristics. However, the use of other types of UAVs would allow less spatial coverage, but more detailed point datasets (i.e. multi-rotary $U A V s$ ).

Passalacqua et al. (2015) suggested four main factors in identifying the most appropriate method in landscape studies: (i) the spatial extent of the area to be acquired, (ii) the point density needed to represent the surface accurately (see Fig. 9), (iii) the need for detailed representation versus elimination of vegetation, and (iv) the ability to penetrate water. For a study site like Los Aguarales badlands, the combination of different techniques has resulted in an excellent multiscale approach to assess geomorphological processes, although the ideal approach would be to obtain highquality data over a range of spatial scales using only one technique. Our multiscale approach provides the opportunity for a cheap and fast way of collecting data and much finer scale observations. Each technique shows different strengths and weaknesses (Fig. 10). Castillo et al. (2012) compared the accuracy of several field methods for measuring gully erosion, and calculated the costs of each technique, concluding that the cost of TLS is 10 times higher than the cost of terrestrial SfM photogrammetry. TLS has more disadvantages for acquiring survey data, and SfM techniques (terrestrial and aerial) are powerful tools for measuring and mapping geomorphological processes in complex semiarid badland systems. Drawbacks to TLS are high costs, difficulties

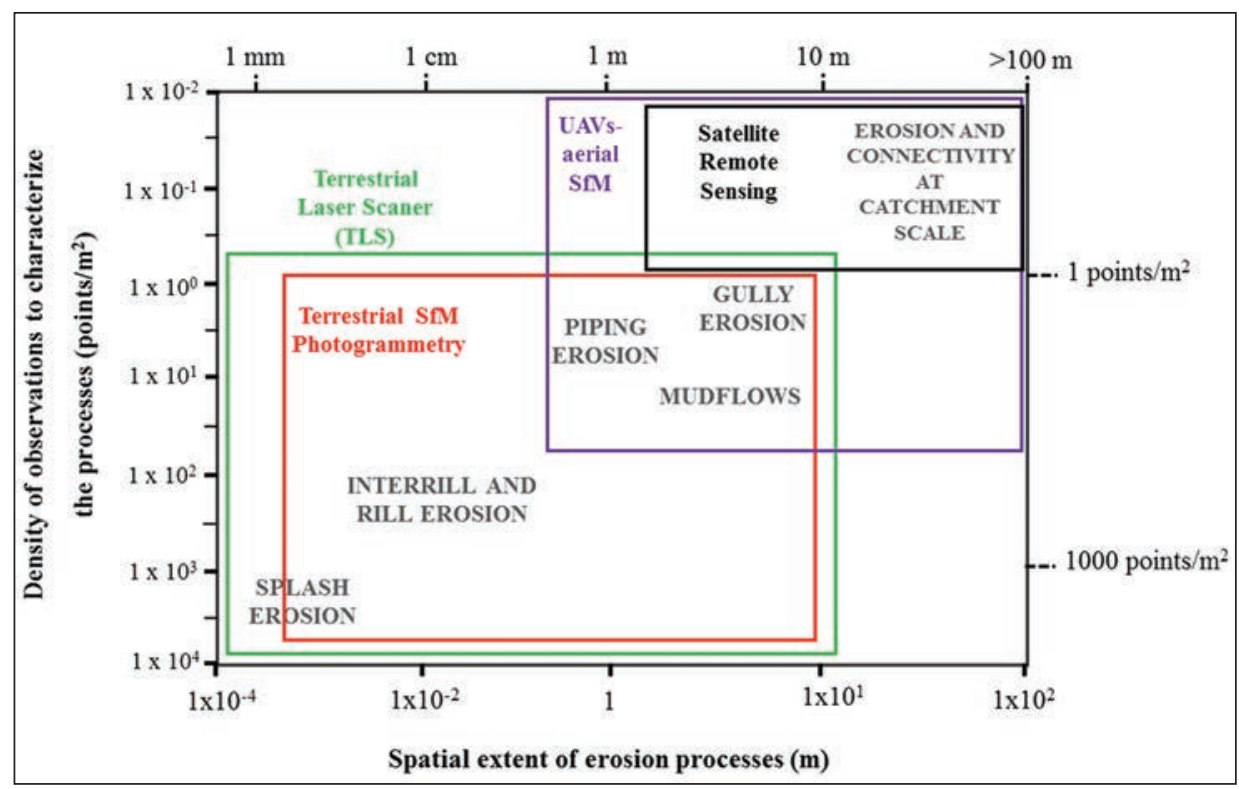

Figure 9. Spatial extent of erosion processes $(m)$ and density of observations to characterize these (points $/ \mathrm{m}^{2}$ ) using non-invasive new technologies (Terrestrial SfM photogrammetry, Terrestrial Laser Scanner, aerial SfM-UAVs, and satellite remote sensing) (Modified from Brasington et al., 2012). 
in inaccessible terrains and the fact that it is time consuming; it also still requires expensive equipment and specialized users. Terrestrial SfM photogrammetry has logistical and mobility advantages and improves precision with low cost equipment. Image acquisition is faster with aerial and terrestrial SfM than TLS, but data analysis is a time consuming task requiring a great deal of computing capacity. The main differences between aerial and terrestrial SfM are the different geometry of the scene, the camera position and orientations. However, UAVs need technical and financial resources, and nowadays one of the main problems is government regulations that have become stringent in several countries for UAV operations.

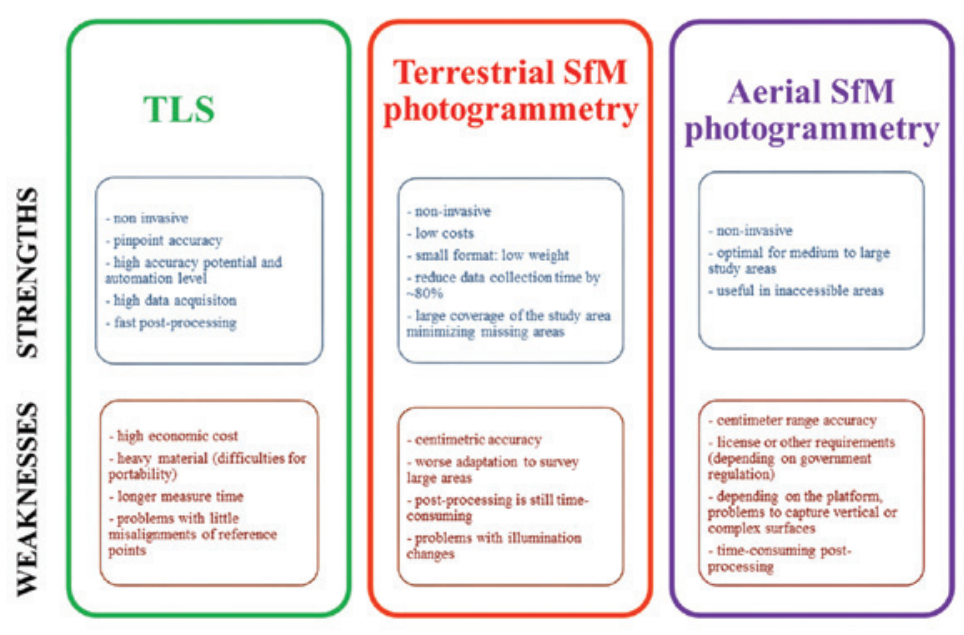

Figure 10. Strengths and weaknesses of Terrestrial Laser Scanner, terrestrial SfM photogrammetry and aerial SfM photogrammetry (UAV) for studying geomorphological studies in badland areas.

Piégay et al. (2015) postulated that new methodologies have been used to address classic questions in the field, rather than entirely new ones, and proposed that emerging questions on methodological issues should also be considered (i.e. accuracy, precision, uncertainty and validation). According to Viles (2016) and other geomorphologists we believe that important challenges still remain: (i) we need skills in interpreting the data obtained, (ii) we need to improve temporal resolution, and (iii) we should not forget its significance for geomorphology and soil erosion studies.

\subsection{Ongoing research}

We have identified three new tasks as further objectives of this research:

(i) We should improve the temporal resolution, because the relatively long time taken for the different surveys could limit interpretation of erosion processes and landscape evolution. Nichols et al. (2016) suggested that high temporal resolution is critical for identifying subsurface erosion processes. In that 
respect, time-lapse photography could be an important complement to this study and to the new technologies that are based on topographic measurement. The installation of two cameras collecting stereo images would allow the use of standard SfM photogrammetry techniques to study geomorphic changes (Nichols et al., 2016). Other authors used a fixed terrestrial laser scanner that can operate continuously in the field (Picard et al., 2016).

(ii) To obtain a better understanding of piping activity and geomorphological dynamics in Los Aguarales badlands we should carry out an in-depth study on the soil characteristics that influence piping processes. A preliminary study (Ferrer, 2016) carried out detailed analyses of 0-5 cm soil samples in different forms but the results did not show clear differences and patterns. In-depth profiles should be studied because different authors (i.e. Verachtert et al., 2013; Bernatek-Jakiel et al., 2016) have indicated that pipes developed on the boundary of B and C soil horizons. We should focus on soil characteristics that can affect piping processes, such as texture, bulk density, $\mathrm{pH}$, exchangeable cations and sodium absorption ratio (SAR).

(iii) Los Aguarales badlands have high geotourism potential and they should constitute a significant element of the tourism development strategy (Zglobicky et al., submitted). In 2015, Los Aguarales badlands were classified as a geomorphosite by the Regional Government, which considered that the site should have a protective, scientific, educational and tourist function. Our study serves as scientific advancement in understanding geomorphological dynamics in the study area. However, we should also make a greater effort to demonstrate the relevance of our discipline to a wider audience, and disseminate the TLS and terrestrial and aerial SfM photogrammetric results. We believe that the outcomes obtained in this research should be used to attract tourists and promote the area.

\section{Conclusions}

This paper presents a multiscale approach using three different technologies (TLS-LiDAR, terrestrial SfM photogrammetry and aerial SfM-UAVs), to assess geomorphological processes in a semiarid complex badland area. The results obtained in this preliminary research have showed the possibilities of a multiscale approach using new technologies to assess geomorphological and erosion processes, although longterm studies will be necessary to understand geomorphological dynamics and obtain erosion rates. Los Aguarales badlands is a miniature geomorphological laboratory that can contribute to geomorphological and landform evolution studies at different scales.

The very high spatial resolution of the point clouds obtained with TLS and terrestrial SfM photogrammetry, has allowed preliminary identification of numerous spatial details, geomorphological dynamics and topographical changes. However, measured topographical changes are very low, and these values fall within the range of the acquisition error of the devices used. UAVs have allowed work at larger scales, mapping piping processes, and could be seen as an advantage for time-effective data acquisition of larger areas. 
To sum up, spatial scales introduce complexity into geomorphology, but all scales must be taken into account in geomorphological studies. Following the high spatial resolution and multiscale approach applied here, a new perspective for geomorphological studies has been presented. However, further investigations, related to accuracy, longterm erosion rates and statistical modelling of geomorphological processes are required, together with physico-chemical soil characterization.

\section{Acknowledgments}

This research was supported by DESEMON, ESPAS and eTERA 3D projects (CGL2014-52135-C3-3-R, CGL2015- 65569-R and CGL2014-54822-R, funded by the MINECO-FEDER). The "Geomorphology and Global Change" and the "Climate, water, global change and natural systems" research groups were financed by the Aragón Government and the European Social Fund (ESF-FSE). We would like to thank the Spectrum-Radiometry and Environmental Remote Sensing Laboratory (ERTAlab, University of Zaragoza) for helping in the fieldwork with the GPS (LEICA VIVA HS15 CS10 GNSS) (scientific and technological infrastructure co-financed by FEDER, UNZA10-4E-488). Special thanks to Teresa Lamelas, María Sebastián and Teodoro Lasanta for helping with the fieldwork. Estela Nadal-Romero is the recipient of a Ramón y Cajal postdoctoral contract (Spanish Ministry of Economy and Competitiveness).

\section{References}

Ballesteros, J.A., Corona, C., Stoffel, M., Lucía-Vela, A., Bodoque, J.M. 2015. Combining terrestrial laser scanning and root exposure to estimate erosion rates. Plant and Soil 394 (12), 127-137. http://doi.org/10.1007/s11104-015-2516-3.

Bechet, J., Duc, J., Jaboyedoff, M., Loye, A., Mathys, N. 2015. Erosion processes in black marl soils at the millimetre scale: preliminary insights from an analogous model. Hydrological Earth System Science 19, 1849-1855. http://doi.org/10.5194/hess-19-1849-2015.

Bernatek-Jakiel, A., Kacprzak, A., Stolarczyk, M. 2016. Impact of soil characteristics on piping activity in a mountainous area under a temperate climate (Bieszczady Mts., Eastern Carpathians). Catena 141, 117-129. http://doi.org/10.1016/j.catena.2016.03.001.

Bernatek-Jakiel, A., Kondracka, M. 2016. Combining geomorphological mapping and near surface geophysics (GPR and ERT) to study piping systems. Geomorphology 274, 193-209. http:// doi.org/10.1016/j.geomorph.2016.09.018.

Bocco, G. 1991. Gully erosion, processes and models. Progress in Physical Geography 15 (4), 392-406. http://doi.org/10.1177/030913339101500403.

Brasington, J., Vericat, D., Rychkov, I. 2012. Modeling river bed morphology, roughness, and surface sedimentology using high resolution terrestrial laser scanning. Water Resources Research 48 (11), W11519. http://doi.org/10.1029/2012WR012223.

Bryan, R.B., Yair, A. (Eds.) 1982. Badland Geomorphology and Piping. GeoBooks, Norwich (408 pp.).

Calvo-Cases, A., Boix-fayos, C., Arnau-Rosalen, E., Roxo, M.J. 2011. Gullies and rills on sodic soils. Petrer (Alicante, Spain). Cuadernos de Investigación Geográfica 37 (1), 25-40. http:// doi.org/10.18172/ cig.1244.

Cammeraat, E.L.H. 2004. Scale dependent thresholds in hydrological and erosion response of a semi-arid catchment in Southeast Spain. Agriculture, Ecosystems and Environment 104 (2), 317-332. http://doi.org/10.1016/j.agee.2004.01.032. 
Castillo, C., Pérez, R., James, M.R., Quinton, J.N., Taguas, E.V., Gómez, J.A. 2012. Comparing the accuracy of several field methods for measuring gully erosion. Soil Science Society of America Journal 76 (4), 1319-1332. http://doi.org/10.2136/sssaj2011.0390.

Castillo, C., James, M.R., Redel-Macías, M.D., Pérez, R., Gómez, J.A. 2015. SF3M software: 3-D photo-reconstruction for non-expert users and its application to a gully network. SOIL 1,583594. http://doi.org/10.5194/soil-1-583-2015.

Church, M. 2010. The trajectory of geomorphology. Progress in Physical Geography 34 (3), 265286. http://doi.org/10.1177/0309133310363992.

Desir, G., Marín, C. 2011. Influence of piping processes on the relief evolution. Bardenas Reales (Navarra, Spain). Cuadernos de Investigación Geográfica 37 (1), 67-78. http://doi. org/10.18172/cig.1246.

Desir, G., Marín, C. 2013. Role of erosion processes on the morphogenesis of a semiarid badland area. Bardenas Reales (NE Spain). Catena 106, 83-92. http://doi.org/10.1016/j.catena.2013.02.011.

D’Oleire-Oltmanns, S., Marzolff, I., Peter, K., Ries, J. 2012. Unmanned Aerial Vehicle (UAV) for Monitoring Soil Erosion in Morocco. Remote Sensing 4 (12), 3390-3416. http://doi. org/10.3390/rs4113390.

Eltner, A., Baumgart, P. 2015. Accuracy constraints of terrestrial Lidar data for soil erosion measurement: application to a Mediterranean field plot. Geomorphology 245, 243-254. http://doi.org/10.1016/j.geomorph.2015.06.008.

Eltner, A., Baumgart, P., Maas, H.G., Faust, D. 2015. Multi-temporal UAV data for automatic measurement of rill and interrill erosion on loess soil. Earth Surface Processes and Landforms 40 (6), 741-755. http://doi.org/10.1002/esp.3673.

Eltner, A., Kaiser, A., Castillo, C., Rock, G., Neugirg, F., Abellán, A. 2016a. Image-based surface reconstruction in geomorphometry-merits, limits and developments. Earth Surface Dynamics 4 (2), 359-389. http://doi.org/10.5194/esurf-4-359-2016.

Eltner, A., Schneider, A., Maas, H.G. 2016b. Integrated processing of high resolution topographic data for soil erosion assessment considering data acquisition schemes and surface properties. The International Archives of the Photogrammetry, Remote Sensing and Spatial Information Science, XLI-B5, 813-819.

Faulkner, H. 2013. Badlands in marl lithologies: A field guide to soil dispersion, subsurface erosion and piping-origin gullies. Catena 106, 42-53. http://doi.org/10.1016/j.catena.2012.04.005.

Faulkner, H., Alexander, R., Teeuw, R., Zukovskyj, P. 2004. Variations in soil dispersivity across a gully head displaying shallow subsurface pipes. Earth Surface Processes and Landforms 29 (9), 1143-1160. http://doi.org/10.1002/esp.1109.

Ferrer, V. 2016. Estudio geomorfológico en los badlands de los Aguarales de Valpalmas (Zaragoza) mediante la aplicación de nuevas tecnologías. Unpublished Master Thesis.

Gallart, F., Marignani, M., Pérez-Gallego, N., Santi, E., Maccherini, S. 2013. Thirty years of studies on badlands, from physical to vegetational approaches. A succinct review. Catena 106, 4-11. http://doi.org/10.1016/j.catena.2012.02.008.

García-Ruiz, J.M. 2011. Una revisión de los procesos de sufosión o piping en España. Cuadernos de Investigación Geográfica 37 (1), 7-23. http://doi.org/10.18172/cig.1243.

García-Ruiz, J.M. 2015. Why geomorphology is a global science. Cuadernos de Investigación Geográfica 41 (1), 87-105. http://doi.org/10.18172/cig.2652.

García Ruiz, J.M., López-Bermúdez, F. 2009. La erosión del suelo en España. Sociedad Española de Geomorfología, Zaragoza, 441 pp.

García-Ruiz, J.M., Nadal-Romero, E., Lana-Renault, N., Beguería, S. 2013. Erosion in Mediterranean landscapes: changes and future challenges. Geomorphology 198, 20-36. http://doi.org/10.1016/j. geomorph.2013.05.023. 
García-Ruiz, J.M., Beguería, S., Nadal-Romero, E., González-Hidalgo, J.C., Lana-Renault, N., Sanjuán, Y. 2015. A meta-analysis of soil erosion rates across the world. Geomorphology 239, 160-173. http://doi.org/10.1016/j.geomorph.2015.03.008.

García-Ruiz, J.M., Beguería, S., Lana-Renault, N., Nadal-Romero, E., Cerdà, A. 2017. Ongoing and emerging questions in water erosion studies. Land Degradation \& Development 28 (1), 5-21. http://doi.org/10.1002/ldr.2641.

Girardeau-Montaut, D., Roux, R.M., Thibault, G. 2005. Change detection on points cloud data acquired with a ground laser scanner. In: Workshop Laser Scanning 2005, ISPRS, Enschede, 6 pp.

Gómez-Gutiérrez, A., Schnabel, S., Berenguer-Sempere, F., Lavado-Contador, F., Rubio-Delgado, J. 2014. Using 3D photo-reconstruction methods to estimate gully headcut erosion. Catena 120,91-101. http://doi.org/10.1016/j.catena.2014.04.004.

Gómez-Gutiérrez, A., Schnabel, S., Conoscenti, C., Caraballo-Arias, N.A., Ferro, V., Di Stefano, C., Blasco Sanjosé, J.J., Angileri, S.E., De Matías, J., Berenguer-Sempere, F. 2016. Production of 3D models for different morphologies and scales using structure from motion techniques and terrestrial pictures. Cuaternario y Geomorfología 30 (2), 23-35. http://doi. org/10.17735/cyg.v30i1-2.39594.

Higgins, C.G. 1990. Gully development. In: C.G. Higgins, D.R. Coates, (Eds.), Groundwater geomorphology: the role of subsurface water in earth-surface processes and landforms, Geological Society of America Special Paper 252, 139-156.

Jones, J.A.A. 2004. Soil piping and its hydrogeomorphic function. Cuaternario y Gemorfología 8 (3-4), 77-102.

Kaiser, A., Neugirg, F., Rock, G., Müller, C., Haas, F., Ries, J., Schmidt, J. 2014. Small-scale surface reconstruction and volume calculation of soil erosion in complex Moroccan Gully morphology using Structure from Motion. Remote Sensing 6 (8), 7050-7080. http://doi.org/10.3390/rs6087050.

Martínez-Casasnovas, J.A. 2003. A spatial information technology approach for the mapping and quantification of gully erosion. Catena 50 (2), 293-308. http://doi.org/10.1016/S03418162(02)00134-0.

Martínez-Murillo, J.F., Nadal-Romero, E., Regüés, D., Cerdà, A., Poesen, J. 2013. Soil erosion and hydrology of the western Mediterranean badlands throughout rainfall simulation experiments: A review. Catena 106, 101-112. http://doi.org/10.1016/j.catena.2012.06.001.

Marzolff, I., Ries, J.B.2011.Piping as a process of gully erosion in small format aerial photography. A short note. Cuadernos de Investigación Geográfica 37 (1), 115-120.

Mathys, N., Klotz, S., Esteves, M., Descroix, L., Lapetite, J.M. 2005. Runoff and erosion in the Black Marls of the French Alps: observations and measurements at the plot scale. Catena 63 (2-3), 261-281. 10.1016/j.catena.2005.06.010.

Nadal-Romero, E., Latron, J., Martí-Bono, C., Regüés, D. 2008. Temporal distribution of suspended sediment transport in a humid Mediterranean badland area: The Araguás catchment, Central Pyrenees. Geomorphology 97 (3-4), 601-6116. http://doi.org/10.1016/j.geomorph.2007.09.009.

Nadal-Romero, E., Revuelto, J., Errea, P., López-Moreno, J.I. 2015. The application of terrestrial laser scanner and SfM photogrammetry in measuring erosion and deposition processes in two opposite slopes in a humid badlands area (Central Spanish Pyrenees). SOIL 1, 561-573. http://doi.org/10.5194/soil-1-561-2015.

Neugirg, F., Kaiser, A., Huber, A., Heckmann, T., Schindewolf, M., Schmidt, J., Becht, M., Haas, F. 2016a. Using terrestrial LiDAR data to analyse morphodynamics on steep unvegetated slopes driven by different geomorphic processes. Catena 142, 269-280. http://doi.org/10.1016/j. catena.2016.03.021.

Neugirg, F., Stark, M., Kaiser, A., Vlacilova, M., Della Seta, M., Vergari, F., Schmidt, J., Becht, M., Haas, F. 2016b. Erosion processes in calanchi in the Upper Orcia Valley, Southern Tuscany, Italy based on multitemporal high-resolution terrestrial LiDAR and UAV surveys. Geomorphology 269, 8-22. http://doi.org/10.1016/j.geomorph.2016.06.027. 
Nichols, M.H., Nearing, M., Hernandez, M., Polyajov, V.O. 2016. Monitoring channel head erosion processes in response to an artificially induced abrupt base level change using time-lapse photography. Geomorphology 265, 107-116. http://doi.org/10.1016/j.geomorph.2016.05.001.

Passalacqua, P., Belmont, P., Staley, S.M., Simley, J.D., Arrowsmith, J.R., Bode, C.A., Crosby, C., Delong, S.B., Glenn, N., Kelly, S.A., Lague, D., Sangireddy, H., Schaffrath, K., Tarboton, D.G., Wasklewicz, T., Weathon, J.M. 2015. Analysing high resolution topography for advancing the understanding of mass and energy transfer through landscapes: A review. Earth-Science Reviews 148, 174-193. http://doi.org/10.1016/j.earscirev.2015.05.012.

Picard, G., Arnaud, L., Panel, J.M., Morin, S. 2016. Design of a scanning laser meter for monitoring the spatio-temporal evolution of snow depth and its application in the Alps and in Antarctica. The Cryosphere 10, 1495-1511. http://doi.org/10.5194/tc-10-1495-2016.

Piégay, H., Kondolf, G.M., Minear, J.T., Vaudor, L. 2015. Trends in publications in fluvial geomorphology overtwo decades: a truly new erain the discipline owing to recent technological revolution? Geomorphology 248, 489-500. http://doi.org/10.1016/j.geomorph.2015.07.039.

Revuelto, J., López-Moreno, J. I., Azorín-Molina, C., Zabalza, J., Arguedas, G., Vicente-Serrano, S.M. 2014. Mapping the annual evolution of snow depth in a small catchment in the Pyrenees using the long-range terrestrial laser scanning. Journal of Maps 10 (3), 1-15. http://doi. org/10.1080/17445647.2013. 869268 .

Ries, J., Marzolff, I. 2003. Monitoring of gully erosion in the Central Ebro Basin by large-scale aerial photography taken from a remotely controlled blimp. Catena 50 (2-4), 309-328. http:// doi.org/10.1016/S0341-8162(02)00133-9.

Romero-Díaz, A., Marín Sanleandro, P., Sánchez Soriano, A., Belmonte Serrato, F., Faulkner, H. 2007. The causes of piping in a set of abandoned agricultural terraces in southeast Spain. Catena 69 (3), 282-293. http://doi.org/10.1016/j.catena.2006.07.008.

Smith, M.W., Vericat, D. 2015. From experimental plots to experimental landscapes: topography, erosion and deposition in subhumid badlands from Structure-from-Motion photogrammetry. Earth Surface Processes and Landforms 40 (12), 1656-1671. http://doi.org/10.1002/esp.3747.

Valentin, C., Poesen, J., Li, Y. 2005. Gully erosion: Impacts, factors and control. Catena 63 (2-3), 132-153. http://doi.org/10.1016/j.catena.2005.06.001.

Verachtert, E., Van Den Eeckhaut, M., Martínez-Murillo, J.F., Nadal-Romero, E., Poesen, J., Devoldere, S., Wijnants, N., Deckers, J. 2013. Impact of soil characteristics and land use on pipe erosion in a temperate humid climate: Field studies in Belgium. Geomorphology 192, 1-14. http://doi.org/10.1016/j.geomorph.2013.02.019.

Vergari, F., Della Seta, M., Del Monte, M., Fredi, P., Lupia Palmieri, E. 2013. Long- and short-term evolution of several Mediterranean denudation hot spots: The role of rainfall variations and human impact. Geomorphology 183, 14-27. http://doi.org/10.1016/j.geomorph.2012.08.002.

Vericat, D., Smith, M.W., Brasington, J. 2014. Patterns of topographic change in sub-humid badlands determined by high resolution multi-temporal topographic surveys. Catena 120 , 164-176. http://doi.org/10.1016/j.catena.2014.04.012.

Viles, H. 2016. Technology and geomorphology: Are improvements in data collection techniques transforming geomorphic science? Geomorphology 270, 121-133. http://doi.org/10.1016/j. geomorph.2016.07.011.

Wohl, E., Bierman, P.R., Montgomery, D.R. 2016. Earth's dynamic surface: a perspective on the past 50 years in geomorphology. Geological Society of America Special Papers 523, SPE523-01. http://doi.org/ 10.1130/2016.2523(01).

Zgłobicki, W.,Poesen, J., Cohen, M., Del Monte, M., García-Ruiz, J.M., Ionita, I., Niacsu,L., Machová, Z., Martín-Duque, J.F., Nadal-Romero, E., Pica, A., Rey, F., Solé-Benet, A., Stankoviansky, M., Stolz, C., Torri, D., Soms, J., Vergari, F. (submitted). The potential of permanent gullies in Europe as geomorphosites. Geoheritage. 